Article

\title{
Enriched Mechanical Strength and Bone Mineralisation of Electrospun Biomimetic Scaffold Laden with Ylang Ylang Oil and Zinc Nitrate for Bone Tissue Engineering
}

\author{
Mohan Prasath Mani ${ }^{1}$, Saravana Kumar Jaganathan ${ }^{2,3,4, *}$ and Eko Supriyanto ${ }^{1}$ \\ 1 School of Biomedical Engineering and Health Sciences, Faculty of Engineering, \\ Universiti Teknologi Malaysia, Skudai 81310, Malaysia \\ 2 Department for Management of Science and Technology Development, Ton Duc Thang University, \\ Ho Chi Minh City, Vietnam \\ 3 Faculty of Applied Sciences, Ton Duc Thang University, Ho Chi Minh City, Vietnam \\ 4 IJNUTM Cardiovascular Engineering center, School of Biomedical Engineering and Health Sciences, \\ Faculty of Engineering, Universiti Teknologi Malaysia, Skudai 81310, Malaysia \\ * Correspondence: saravana@tdtu.edu.vn
}

Received: 29 April 2019; Accepted: 6 July 2019; Published: 8 August 2019

\begin{abstract}
Scaffolds supplemented with naturally derived materials seem to be a good choice in bone tissue engineering. This study aims to develop polyurethane (PU) nanofibers added with ylang ylang $(\mathrm{YY})$ and zinc nitrate $\left(\mathrm{ZnNO}_{3}\right)$ using the electrospinning method. Field emission scanning electron microscopy (FESEM) images showed that the diameter of the PU nanofibers $(869 \pm 122 \mathrm{~nm})$ was reduced with the addition of $\mathrm{YY}$ and $\mathrm{ZnNO}_{3}(\mathrm{PU} / \mathrm{YY}-467 \pm 132 \mathrm{~nm}$ and $\mathrm{PU} / \mathrm{YY} / \mathrm{ZnNO}_{3}-290 \pm 163 \mathrm{~nm}$ ). Fourier transform infrared (FTIR), a thermal gravimetric analysis (TGA) and an X-ray diffraction (XRD) analysis confirmed the interactions between PU with YY and $\mathrm{ZnNO}_{3}$. In addition, a thermal gravimetric analysis (TGA) study revealed the improved thermal stability for $P U / Y Y$ and a slight reduction in the thermal stability for $P U / Y Y / Z n N N_{3}$. A tensile test indicated that the addition of $\mathrm{YY}$ and $\mathrm{ZnNO} 3$ (PU/YY-12.32 MPa and PU/YY/ZnNO $3-14.90 \mathrm{MPa}$ ) improved the mechanical properties of the pristine PU (6.83 MPa). The electrospun PU/YY (524 nm) and $\mathrm{PU} / \mathrm{YY} / \mathrm{ZnNO}_{3}(284 \mathrm{~nm})$ showed a reduced surface roughness when compared with the pristine PU $(776 \mathrm{~nm})$ as depicted in the atomic force microscopy (AFM) analysis. The addition of YY and $\mathrm{ZnNO}_{3}$ improved the anticoagulant and biocompatibility nature of the pristine PU. Furthermore, the bone mineralization study depicted the improved calcium deposition in the fabricated composites (PU/YY-7.919\% and PU/YY/ZnNO $3-10.150 \%$ ) compared to the pristine PU (5.323\%). Hence, the developed composites with desirable physico-chemical properties, biocompatibility and calcium deposition can serve as plausible candidates for bone tissue engineering.
\end{abstract}

Keywords: polyurethane; ylang ylang/zinc nitrate; physico-chemical properties; calcium deposition; bone tissue engineering

\section{Introduction}

In bone tissue engineering, artificial bone scaffolds are used to support the remodeling of the bone defects. The bone defects were caused by disease or trauma, which include tumour ablation, bone cysts, osteolysis, and neurosurgical defects [1]. Bone regeneration is a complex process involving the interaction of different cell types such as chondrocytes, mesenchymal stem cells, osteoblasts, osteoclasts and endothelial cells [2]. In bone tissue engineering, the scaffolds play a vital role in 
carrying the cells and also for cellular ingrowth. An ideal scaffold for the bone substitute should be able to resemble the biological and mechanical properties of natural bone tissue [3]. Polymeric scaffold ranging from natural to synthetic has received huge attention in bone tissue engineering, owing to their biocompatibility and biodegradability [4]. Bone tissue engineering is comprised of three components, namely (1) cells (2) scaffolds and (3) growth factors. The scaffold, an important component, is a three-dimensional (3D) structure that can support cell adhesion and proliferation for new tissue growth [5]. Furthermore, the artificial scaffolds should possess a biomimetic structure which could have the ability to mimic the native function of the extracellular matrix (ECM) [6,7]. An artificial ECM-based scaffold shows many advantages like (1) providing the mechanical support required for the cell growth, (2) having the ability to control cell functions (3), and offering an appropriate environment for facilitating the cell attachment [3]. In this study, an artificial ECM-mimicking scaffold was fabricated by electrospinning.

Electrospinning is a cost-effective and versatile technique that generates a fibrous scaffold with a diameter ranging from the micrometre to the nanometre range [8]. The fibrous scaffold possesses a high surface area with a porous structure that can resemble the native ECM structure and is widely used in biomedical applications $[9,10]$. Fibrous scaffolds were reported to enhance the cell adhesion, migration and proliferation [11]. Furthermore, they also provide a superior environment for cellular ingrowth to non-fibrous scaffolds. In this research, polyurethane (PU) is selected for fabricating the scaffold, which is a poly ether-based polymer. PU is selected because it has several advantages, like biocompatibility, biodegradability and a good oxidation stability $[12,13]$. Furthermore, the electrospun scaffolds based on PU were widely used in wound dressing, tissue engineering and drug delivery systems [14-16].

In this research, the polyurethane was added with additives to improve the cellular non-toxic behaviour and also to enhance the mechanical strength, in order to support the new bone tissue. Recently, it was observed that the electrospun scaffolds, added with natural products like essential oils, honey and propolis, have enhanced the cellular response [17-19]. Furthermore, a few studies have reported that the addition of metallic particles into the electrospun scaffold have improved the tensile strength $[20,21]$. Hence, this study aims to fabricate PU blended with a combination of essential oil and metallic particles as a scaffold for bone tissue engineering.

In this research, ylang ylang $(\mathrm{YY})$ oil and Zinc nitrate $\left(\mathrm{ZnNO}_{3}\right)$ were utilized as additives for PU scaffolds. Cananga odorata is known as ylang-ylang (YY), which is a fast-growing tree widely found in the tropical areas of Asia such as Malaysia, Philippines, India, Indonesia and the islands of the Indian Ocean. Ylang-ylang essential oil contains monoterpene hydrocarbons, sesquiterpene hydrocarbons, oxygen-containing monoterpenes, oxygen-containing sesquiterpenes, acetates, benzenoids, benzoates and phenols. The oxygenated fraction of YY essential oil contains the main active components of $\mathrm{p}$-methylanisole, methyl benzoate, benzyl benzoate, benzyl acetate, geranyl acetate, cinnamyl acetate, (E,E)-farnesyl acetate, linalool, geraniol, and benzyl salicylate. Meanwhile, the main active components from the hydrocarbon fraction of ylang-ylang oil are germacrene $\mathrm{D}, \beta$-caryophyllene, $\gamma$-Muurolene and $(\mathrm{E}, \mathrm{E})$-farnesyl acetate. C. odorata is reported to have medicinal properties and is traditionally used for treating various diseases like malaria, asthma pneumonia and stomach ache. Certain studies had reported that the bioactive extracted from the $Y Y$ was reported to possess biomedical properties like antibacterial, antioxidant, antipest, anti-inflammatory and antifungal activities. [22]. $\mathrm{ZnNO}_{3}$ was utilized to improve the mechanical strength of the electrospun scaffold. It has been observed that the scaffold containing zinc particles exhibited a non-toxicity to the osteoprogenitor cells and enhanced the antibacterial activity. In addition to the antibacterial properties, the zinc is reported to support the osteoblast activity, apatite formation and enhanced adhesion and proliferation of osteoblast cells [23]. This study aims to electrospun and test the bone scaffold based on polyurethane added with $\mathrm{YY}$ and $\mathrm{ZnNO}_{3}$. 


\section{Experimental Section}

\subsection{Materials}

Tecoflex EG 80A, medical grade aliphatic polyurethane, was purchased from Lubrizol, Wickliffe, $\mathrm{OH}$, United States. The solvent dimethylformamide (DMF) utilized for dissolving the polymer was supplied from Merck, Burlington, NJ, USA. YY oil was purchased from AEON, Johor, Malaysia. Phosphate buffer saline (PBS) and sodium chloride physiological saline $(0.9 \% w / v)$ were obtained from Sigma-Aldrich, Kuala Lumpur, Malaysia. $\mathrm{ZnNO}_{3}$ was supplied from Sigma Aldrich, Gillingham, UK. The clotting reagents used for the coagulation study were obtained from Diagnostic Enterprise, Thiruvananthapuram, India.

\subsection{Preparation of PU and Their Composite Solution}

The weight concentration of PU used was 9\%, and it was obtained by dissolving $0.450 \mathrm{~g}$ in $5 \mathrm{~mL}$ of DMF. Similarly, the homogeneous solution of $Y Y(4 \mathrm{v} / \mathrm{v} \%)$ and $\mathrm{ZnNO}_{3}(4 \mathrm{wt} \%)$ was prepared by adding $120 \mu \mathrm{L}$ and $0.120 \mathrm{~g}$ of $\mathrm{YY}$ and $\mathrm{ZnNO}_{3}$ in $3 \mathrm{~mL}$ of DMF. Finally, the prepared $\mathrm{YY}$ and $\mathrm{ZnNO}_{3}$ was added to the PU homogenous solution to make PU/YY and PU/YY/ZnNO 3 at a volume ratio of 8:1 $\mathrm{v} / \mathrm{v} \%$ and 8:0.5:0.5 $\mathrm{v} / \mathrm{v} \%$ respectively.

\subsection{Electrospinning of Prepared Solutions}

The electrospinning equipment (Progene Link Sdn Bhd, Selangor, Malaysia) was used to convert the prepared solutions into the fibrous scaffold, and this was done at room temperature with a humidity of $55 \%$. The operation parameters were kept constant for electrospinning of all of the prepared solutions. The optimized voltage, flow rate and collector distance were $11.5 \mathrm{kV}, 0.3 \mathrm{~mL} / \mathrm{h}$ and $20 \mathrm{~cm}$, respectively. The obtained fibers that were collected used aluminium foil placed on the collector drum. The fibers were dried under vacuum to remove any residues that were present.

\subsection{Characterization}

\subsubsection{Field Emission Scanning Electron Microscopy (FESEM)}

The morphological analysis of the fibrous membrane was done using the FESEM unit (Hitachi SU8020, Tokyo, Japan). Prior to imaging, membranes were sputtered with gold and imaged for different magnifications. The mean fiber diameter of the electrospun membranes was determined using Image J by selecting 30 locations from the particular captured image.

\subsubsection{Fourier Transform Infrared Spectroscopy (FTIR)}

The infrared spectrum of the electrospun membranes was done using Nicolet iS 5, Thermo Fischer Scientific, Waltham, MA, USA. The ATR crystal that was used was zinc selenium. For each sample, the 32 scans were performed in the wavelength range of $600-4000 \mathrm{~cm}^{-1}$ at a resolution of $4 \mathrm{~cm}^{-1}$.

\subsubsection{Contact Angle Measurements}

The water contact angle, which depicts the wettability of the fabricated membranes, was measured by video contact angle (VCA) unit (AST products, Inc., Billerica, MA, USA). Drops of deionized water $(0.5 \mu \mathrm{L})$ were applied on the electrospun surfaces, and using high resolution camera a static image was captured within a few seconds. The contact angles for the static image were calculated using computer integrated software, and the experiment was repeated three times. 


\subsubsection{X-ray Diffraction}

An X-ray diffractometer analyser (Rigaku, Tokyo, Japan) with $\mathrm{CuK} \alpha$ radiation was used to analyse the crystallographic changes in the electrospun membranes. Patterns were attained in the $2 \theta$ range of $10-90^{\circ}$ with a scanning rate of $10^{\circ} / \mathrm{min}$.

\subsubsection{Thermal Behaviour}

The thermal behaviour of $\mathrm{PU}$ and their composite was determined using a thermal gravimetric analysis (TGA) unit (PerkinElmer, Waltham, MA, USA). The thermal behaviour was studied between the temperature ranges of 30 to $1000{ }^{\circ} \mathrm{C}$ with a heating rate of $10^{\circ} \mathrm{C} / \mathrm{min}$ under a nitrogen atmosphere.

\subsubsection{Tensile Test Analysis}

The mechanical performance of the electrospun membranes was determined by a uniaxial tester machine (Gotech Testing Machines, AI-3000, Taichung City, Taiwan). The samples with a size of $40 \times 15 \mathrm{~mm}^{2}$ were cut and clamped in the grips of the machine with a gauge length of $20 \mathrm{~mm}$. The experiment was performed at a cross-head speed of $10 \mathrm{~mm} / \mathrm{min}$ with a load cell of $500 \mathrm{~N}$. The average tensile strength was determined from the machine plotted stress-strain curve.

\subsubsection{Atomic Force Microscopy (AFM) Analysis}

The surface topography of the nanofibrous scaffolds was evaluated by an atomic force microscopy unit (NanoWizard ${ }^{\circledR}$, JPK Instruments, Berlin, Germany) in taping mode. The experiment was performed in a normal atmosphere and the scanning area of $20 \times 20 \mu \mathrm{m}^{2}$ with a 256-sample resolution.

\subsection{Mineralization Testing}

The mineralization test was done using simulated body fluid (SBF) to determine the bioactivity of the electrospun membranes. A small cut sample of the electrospun membranes was soaked in $1.5 \times \mathrm{SBF}\left(\mathrm{pH} 7.4 ; 37^{\circ} \mathrm{C}\right.$ ) and incubated for 14 days. The soaked samples were removed, and after 14 days they were cleaned with distilled water. After this, the samples were dried at $37^{\circ} \mathrm{C}$. The dried electrospun membranes were examined through scanning electron microscopy (SEM) unit (Hitachi Tabletop TM3000, Tokyo, Japan) equipped with Energy Dispersive X-Ray Spectroscopy (EDX) to determine the amount of calcium deposition.

\subsection{Coagulation Assays}

\subsubsection{Activated Partial Thromboplastin Time (APTT) Assay}

Electrospun PU and its composites scaffolds were cut into square samples and incubated in PBS at $37^{\circ} \mathrm{C}$ for $30 \mathrm{~min}$ before starting the assay. First, the samples were placed with $50 \mu \mathrm{L}$ of obtained PPP for $1 \mathrm{~min}$ at $37^{\circ} \mathrm{C}$, followed by adding $50 \mu \mathrm{L}$ of rabbit brain cephaloplastin reagent for $3 \mathrm{~min}$ at $37^{\circ} \mathrm{C}$. Finally, the mixture was activated by adding $50 \mu \mathrm{L}$ of $\mathrm{CaCl}_{2}$ and stirred using a sterile steel needle. The time taken for the clot formation was noted using a chronometer.

\subsubsection{Prothrombin Time (PT) Assay}

Electrospun PU and its composites scaffolds were cut into square samples and incubated in PBS for $30 \mathrm{~min}$ at $37^{\circ} \mathrm{C}$. To begin the assay, the samples were placed with $50 \mu \mathrm{L}$ of PPP for $1 \mathrm{~min}$, followed by adding $50 \mu \mathrm{L}$ of $\mathrm{NaCl}$-thromboplastin reagent (Factor III) and stirring using a sterile steel needle. The time taken for the formation of clot was noted as PT.

\subsubsection{Hemolysis Assay}

To start this assay, both PU and its composites scaffolds were soaked in physiological saline $(0.9 \%$ $\mathrm{w} / \mathrm{v}$ ) at $37^{\circ} \mathrm{C}$ for $30 \mathrm{~min}$. Then, they were exposed to the mixture of citrated blood and diluted saline 
(4:5) for $1 \mathrm{~h}$ at $37^{\circ} \mathrm{C}$. After this, the exposed samples were taken out, and the mixtures were centrifuged at $3000 \mathrm{rpm}$ for $15 \mathrm{~min}$. Finally, the supernatant was aspirated, and the absorbance was recorded at $542 \mathrm{~nm}$, which represents the damage of red blood cell (RBCs). The hemolytic percentage was calculated using the following formula [18]:

$$
\text { Hemolysis percentage }(\mathrm{HP})=(\mathrm{TS}-\mathrm{NC}) /(\mathrm{PC}-\mathrm{NC}) \times 100
$$

where TS, NC, and PC are the measured absorbance values of the test sample, negative control, and positive control at $542 \mathrm{~nm}$, respectively.

\subsection{MTS Assay}

An MTS (3-(4,5-dimethylthiazol-2-yl)-5-(3-carboxymethoxyphenyl)-2-(4-sulfophenyl)-2H-tetrazolium) assay was used to determine the cell growth levels on electrospun scaffolds after a 5 day culture. A small cut piece of electrospun scaffolds was placed into 96 well plates and sterilized with $70 \%$ ethanol for $10 \mathrm{~min}$ and cleansed with PBS. After this, human dermal fibroblast (HDF) cells were seeded into each well, in which scaffolds were placed with a density of $10 \times 10^{3}$ cells $/ \mathrm{cm}^{2}$ and cultured for 5 days. After 5 days, the scaffolds were removed from the medium and further incubated with $20 \%$ of MTS at $37^{\circ} \mathrm{C}$ for four hours. The live cells in the electrospun membranes were measured by taking the absorbance at $490 \mathrm{~nm}$ using a spectrophotometer reader. The experiments were done in triplicate.

\subsection{Statistical Analysis}

All of the experiments were done thrice independently. A one-way ANOVA was performed to calculate the statistical significance $(p<0.05)$ and was expressed as the mean \pm SD. In the case of the qualitative experiments, an illustration of three images is indicated.

\section{Results and Discussion}

\subsection{SEM Investigation}

Figure 1 shows the SEM images of PU and PU nanocomposite fibers prepared using the electrospinning technique. The SEM images depicted that the developed scaffold consists of smooth nanofibers, randomly oriented without any beads. The fiber diameter was calculated using Image $\mathrm{J}$, and the average fiber diameter of PU, PU/YY and PU/YY/ZnNO 3 were found to be $869 \pm 122 \mathrm{~nm}$, $467 \pm 132 \mathrm{~nm}$ and $290 \pm 163 \mathrm{~nm}$ respectively. The fiber diameter analysis showed that the fiber diameter was reduced with the addition of $\mathrm{YY}$ and $\mathrm{ZnNO}_{3}$. Furthermore, we observed a synergistic reduction of the fiber diameter with the addition of $\mathrm{ZnNO}_{3}$ into the polyurethane matrix. The addition of $\mathrm{YY}$ resulted in a reduced fiber diameter due to the active constituents present in the oil. This may have been further pronounced when $\mathrm{ZnNO}_{3}$ was added to the polyurethane matrix. From the FESEM figure, the $\mathrm{ZnNO}_{3}$ particle present on the surface of the fiber was evident, and there might be the possibility of the release of the $\mathrm{ZnNO}_{3}$ particle from the fiber surface. However, owing to the low concentration used, there might be no risk of toxicity to the human cells, as indicated in our MTS assay. Few studies have reported that the electrospun scaffold with a smaller diameter facilitated the enhanced osteoblast growth [24,25]. Our developed composites showed a smaller fiber diameter than the pristine PU, suggesting its suitability for the new bone tissue formation. Cell colonization is considered an important parameter in the biological process, and it influences wound healing, vascularization, tissue engineering and stem cell differentiation. The scaffolds are used to support the ingrowth of cells during colonization [26]. Noriega et al. electrospun a chitosan scaffold and studied the chondrocytes' spreading, proliferation and differentiation. It has been shown that a smaller fiber diameter shows a higher deposition ratio of collagen II/collagen I compared to the lager fiber diameter [27]. In another study, Guo et al. developed scaffolds with fiber diameters of $0.347 \mu \mathrm{m}$, $0.947 \mu \mathrm{m}$, and $6.48 \mu \mathrm{m}$ to examine the proliferation and differentiation of osteoblast cells. It was 
reported that the scaffold with $0.35 \mu \mathrm{m}$ exhibited a higher projected area and increased the expression of Runt-related transcription factor 2 (RUNX2), type I collagen (Col I), alkaline phosphatase (ALP) activity and osteocalcin (OCN), respectively [28]. Hence, the specific surface area of a smaller fiber diameter facilitated the enhanced protein adhesion, causing a large amount of cell attachment on them [29]. In this work, fabricated composites exhibited a reduced fiber diameter compared to the control, which should be favourable to the cell colonization to induce tissue growth. The presence of zinc $(1.9 \%)$ in the polyurethane matrix was confirmed in the EDX study, as shown in Figure 2.

(a)

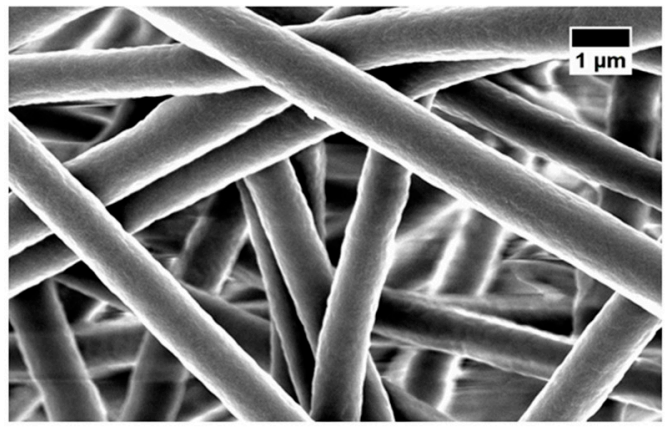

(b)

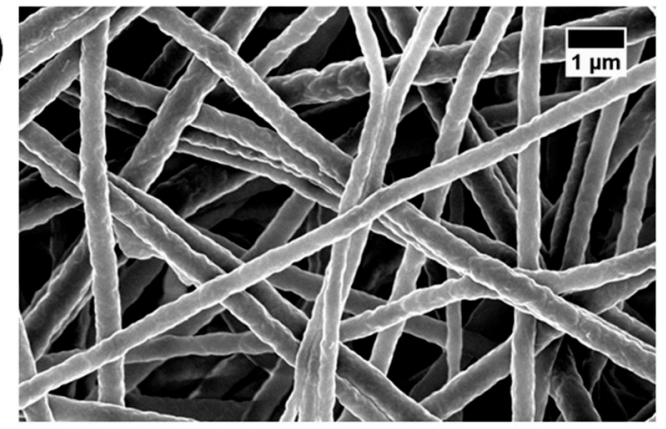

(c)

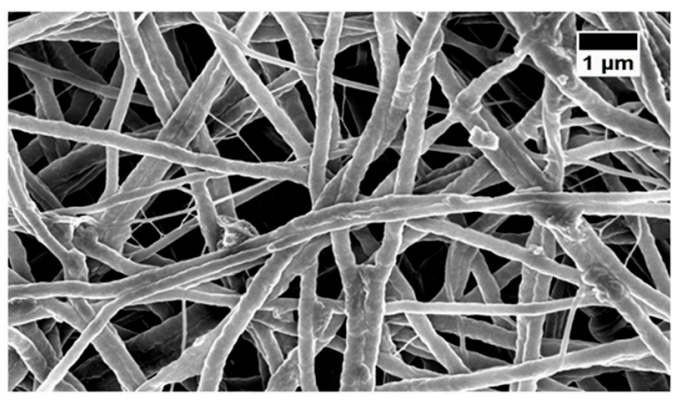

Figure 1. Field Emission Scanning Electron Microscopy (FESEM) images of (a) polyurethane (PU), (b) PU/ylang ylang (YY) and (c) PU/YY/zinc nitrate $\left(\mathrm{ZnNO}_{3}\right)$.

(a)

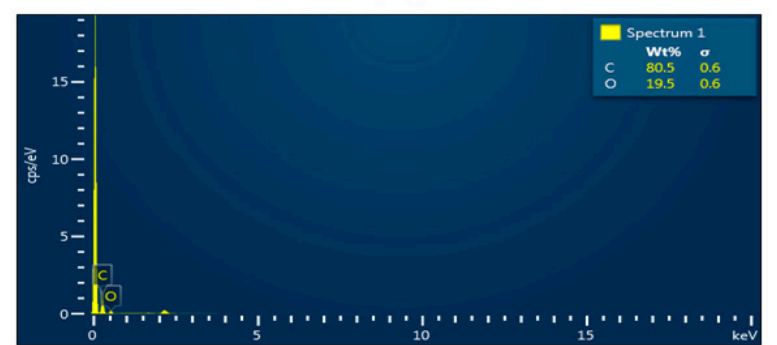

(b)

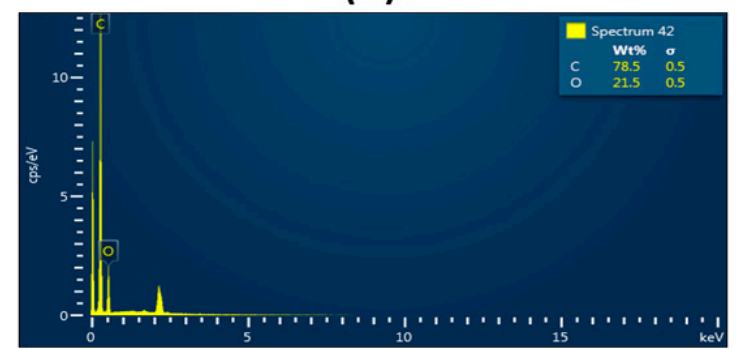

(c)

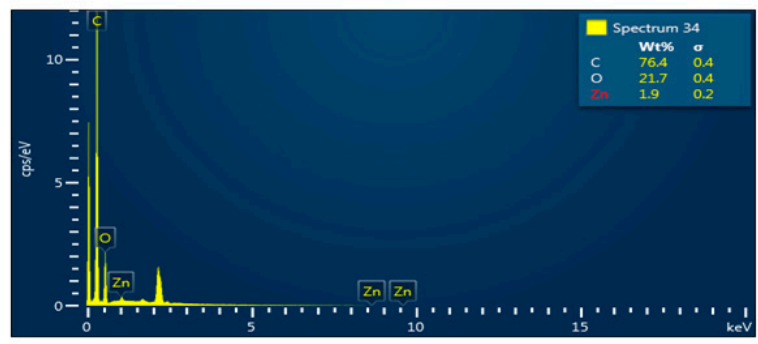

Figure 2. Energy Dispersive X-Ray Spectroscopy (EDX) of (a) PU, (b) PU/YY and (c) PU/YY/ZnNO 3. 


\subsection{IR Analysis}

The IR spectra of the nanofibrous membranes were carried out to examine the functional groups that were present. Figure 3 shows the FTIR spectra of the PU, PU/YY, PU/YY/ZnNO 3 composite membranes. The pristine PU showed characteristic broad bands of $\mathrm{NH}$ stretch at $3323 \mathrm{~cm}^{-1}$, and its vibrations were observed at $1531 \mathrm{~cm}^{-1}$ and $1597 \mathrm{~cm}^{-1}$, respectively. The bands of the $\mathrm{CH}$ group can be observed at $2940 \mathrm{~cm}^{-1}$ and $2854 \mathrm{~cm}^{-1}$, and the band at $1414 \mathrm{~cm}^{-1}$ represents its vibrations. Furthermore, a twin peak is seen at $1702 \mathrm{~cm}^{-1}$ and $1730 \mathrm{~cm}^{-1}$, attributed to the bands of the CO group. Moreover, the characteristic peak was present between the regions of $500-1200 \mathrm{~cm}^{-1}$. The bands at $1220 \mathrm{~cm}^{-1}$, $1105 \mathrm{~cm}^{-1}$ and $770 \mathrm{~cm}^{-1}$ denote the characteristic peaks of PU, which are attributed to C-O-C and $\mathrm{C}-\mathrm{OH}$ stretching vibrations, respectively [17-19]. In the electrospun nanocomposites, the peaks were similar to those of the pristine PU. However, an increase in the intensity was observed in the pristine PU while incorporating $\mathrm{YY}$ and $\mathrm{ZnNO}_{3}$ respectively. The alteration in the peak intensity was due to a strong hydrogen bond formation between the molecules of $\mathrm{YY}$ and $\mathrm{ZnNO}_{3}$ and the molecules of PU [30].

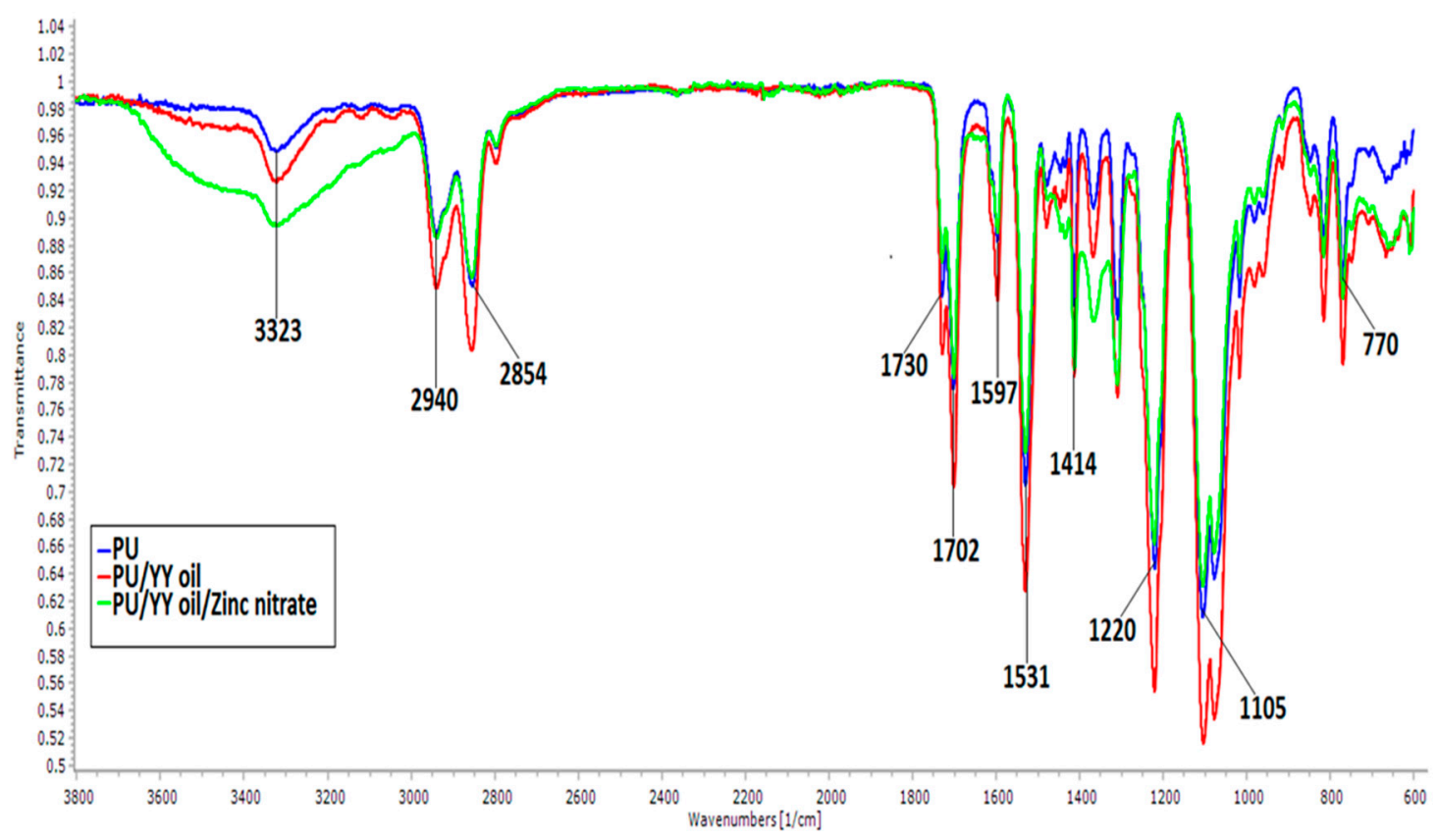

Figure 3. Fourier Transform Infrared Spectroscopy (FTIR) of PU, PU/YY and PU/YY/ZnNO

\subsection{Contact Angle Measurements}

The contact angles measurement was performed to evaluate the wettability and adhesion properties of the developed as-spun membranes. The PU, PU/YY, PU/YY/ZnNO $\mathrm{Zn}_{3}$ membranes contact angle were observed to be $106 \pm 3^{\circ}, 112 \pm 1^{\circ}$, and $86 \pm 1^{\circ}$, respectively. It was shown that the contact angle was increased to $112^{\circ}$ while adding $Y Y$, indicating hydrophobic behaviour, and that it was decreased to $86^{\circ}$ upon adding $\mathrm{ZnNO}_{3}$, suggesting hydrophilic behaviour. Hence, the addition of $\mathrm{ZnNO}_{3}$ improved the wettability of the pristine PU. The wettability design of a scaffold is important in tissue engineering, as it can influence the cell adhesion and proliferation to a higher extent. It was reported that the contact angle in the range of less than $106^{\circ}$ was inappropriate for optimum cell adhesion and proliferation [31]. The contact angle of PU/YY $\left(112^{\circ} \pm 1^{\circ}\right)$ was found to be behind the reported range, which may cause a reduction of the cell adhesion and proliferation. Furthermore, adding $\mathrm{ZnNO}_{3}$ to the PU/YY facilitates the improved wettability $\left(86^{\circ} \pm 1^{\circ}\right)$, which lies in the reported wettability range and is suitable for the improved cell adhesion and proliferation for new tissue growth. Liang et al. electrospun a bone scaffold utilizing PLGA/nHA/graphene oxide. It was found that the developed PLGA/HA/graphene oxide scaffolds displayed hydrophilic behaviour and favoured an enhanced osteoblast cell response [32]. 
Hence, our optimal wettability of the fabricated $\mathrm{PU} / \mathrm{YY} / \mathrm{ZnNO}_{3}$ nanocomposite might serve as a potential candidate for bone tissue engineering.

\subsection{XRD Analysis}

Figure 4 shows the $X R D$ patterns of the pure $P U, P U / Y Y$ and $P U / Y Y Z n{ }_{2} O_{3}$ nanofibers. The pristine PU showed a characteristic broad peak at $20^{\circ}$, which indicates its amorphous behaviour. For the electrospun PU/YY scaffolds, there was no new peak found, apart from the characteristic broad peak at $20^{\circ}$. In the case of $\mathrm{PU} / \mathrm{YY} / \mathrm{ZnNO}_{3}$, there was an extra peak at $8.8^{\circ}$, apart from the broad peak. The peaks were attributed to the crystal plane of $\mathrm{Zn}$ [33]. Hence, the XRD analysis confirms the change in crystalline behaviour of the $\mathrm{PU} / \mathrm{YY} / \mathrm{ZnNO}_{3}$ nanocomposites.

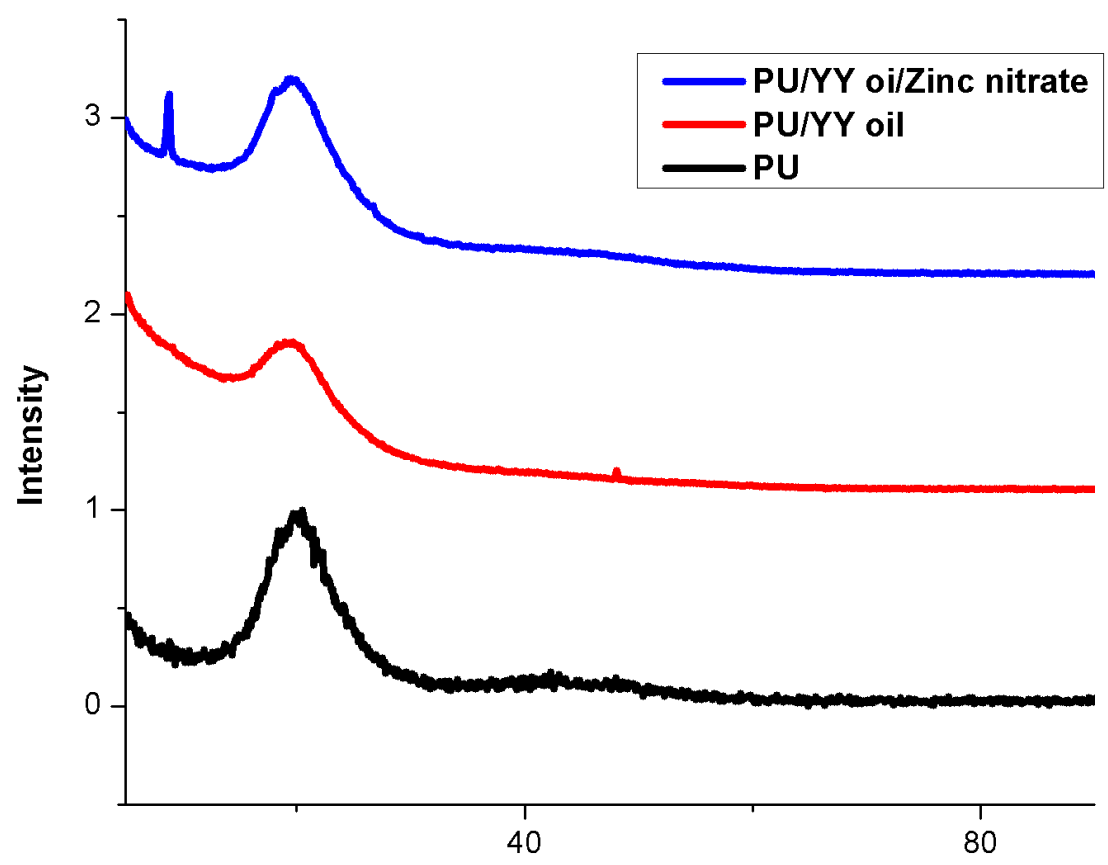

2 Thetta

Figure 4. X-ray Diffraction (XRD) images of PU, PU/YY and PU/YY/ZnNO 3.

\subsection{Thermal Analysis}

The thermal behaviours of $\mathrm{PU}, \mathrm{PU} / \mathrm{YY}$, and $\mathrm{PU} / \mathrm{YY} / \mathrm{ZnNO}_{3}$ were done using TGA, and their respective curves are presented in Figure 5. The results for the thermal analysis depicted that the decomposition temperature of the developed PU/YY nanocomposite is much higher than that of the neat PU fiber, while $\mathrm{PU} / \mathrm{YY} / \mathrm{ZnNO}_{3}$ shows lower decomposition temperature than the pristine PU. The pristine PU exhibited an initial decomposition temperature of $266^{\circ} \mathrm{C}$, and for electrospun PU/YY and $\mathrm{PU} / \mathrm{YY} / \mathrm{ZnNO}_{3}$ it was observed to be $273^{\circ} \mathrm{C}$ and $196{ }^{\circ} \mathrm{C}$, respectively. Hence, the reinforcement of YY improved the thermal stability of the pristine PU, while the addition of $\mathrm{ZnNO}_{3}$ decreased the onset degradation. Jaganathan et al. electrospun polyurethane scaffolds added with zinc nitrate. It was found that the addition of zinc nitrate resulted in a decrease in the onset degradation temperature of PU, which resembles our findings. Furthermore, they attributed this to the evaporation of water or moisture present in the developed film [34]. Further weight loss curves for the fabricated PU, $\mathrm{PU} / \mathrm{YY}$, and $\mathrm{PU} / \mathrm{YY} / \mathrm{ZnNO}_{3}$ are indicated in Figure 6, and a list of weight loss peaks are listed in Table 1 . The pristine PU showed 4 weight loss peaks, whereas the electrospun PU/YY showed only 2 weight loss peaks, indicating a reduced weight loss compared to the pristine PU. However, with the $\mathrm{ZnNO}_{3}$ addition, the number of weight loss peaks increased (5 loss peaks) compared to the pristine PU. This clearly depicted that the added constituents, like $\mathrm{YY}$ and $\mathrm{ZnNO}_{3}$, are integrated within the polyurethane matrix. A decrease in the intensity of the weight loss peak in electrospun $\mathrm{PU} / \mathrm{YY} / \mathrm{ZnNO}_{3}$ 
compared to the pristine PU indicated the reduced weight loss of their fabricated composites. This is quite similar to recent observation where Jaganathan et al. fabricated polyurethane scaffolds added with zinc nitrate. It was observed that the addition of zinc nitrate resulted in a decrease in the weight loss peak intensity of PU, which resembles our findings [34].

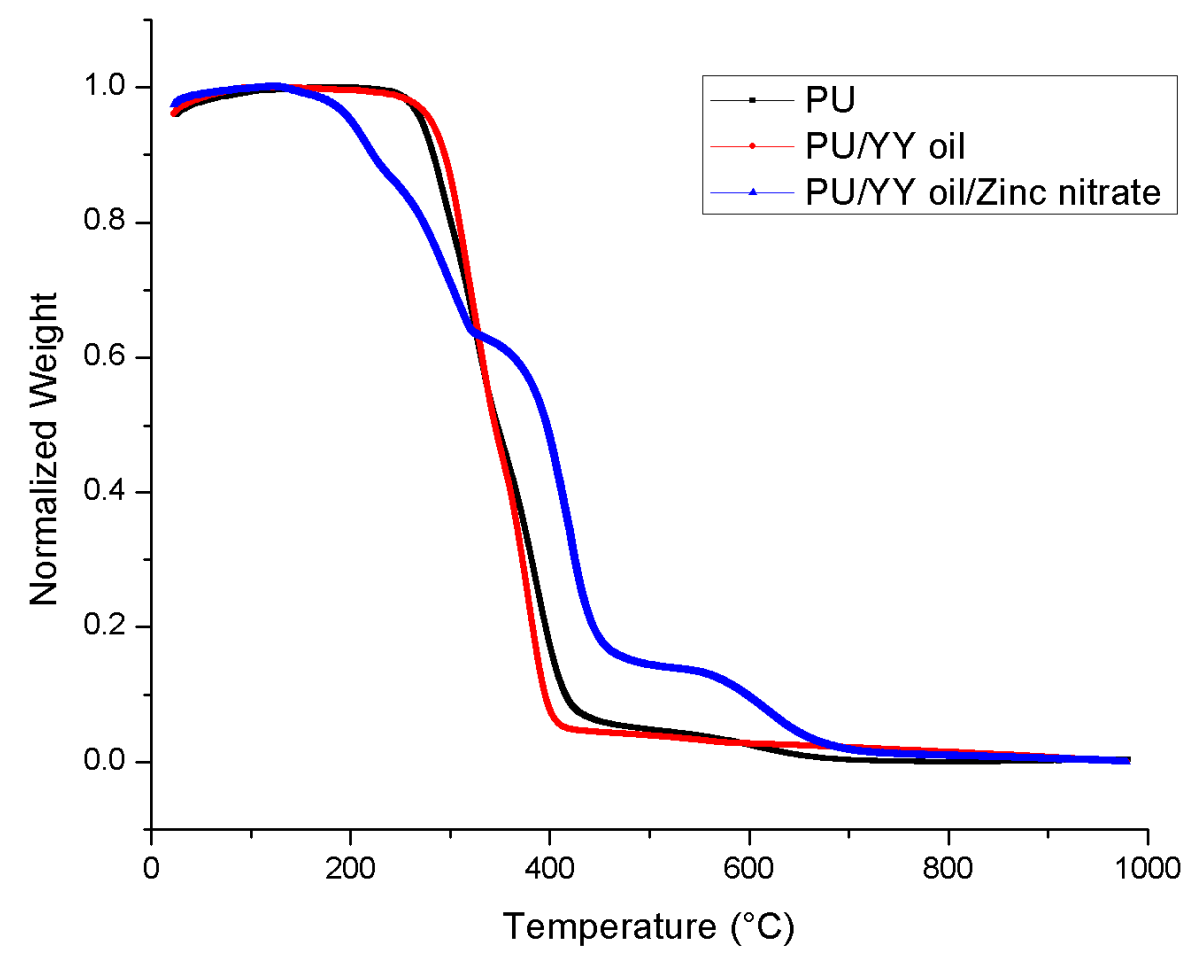

Figure 5. Thermal gravimetric analysis (TGA) of $\mathrm{PU}, \mathrm{PU} / \mathrm{YY}$ and $\mathrm{PU} / \mathrm{YY} / \mathrm{ZnNO}_{3}$.

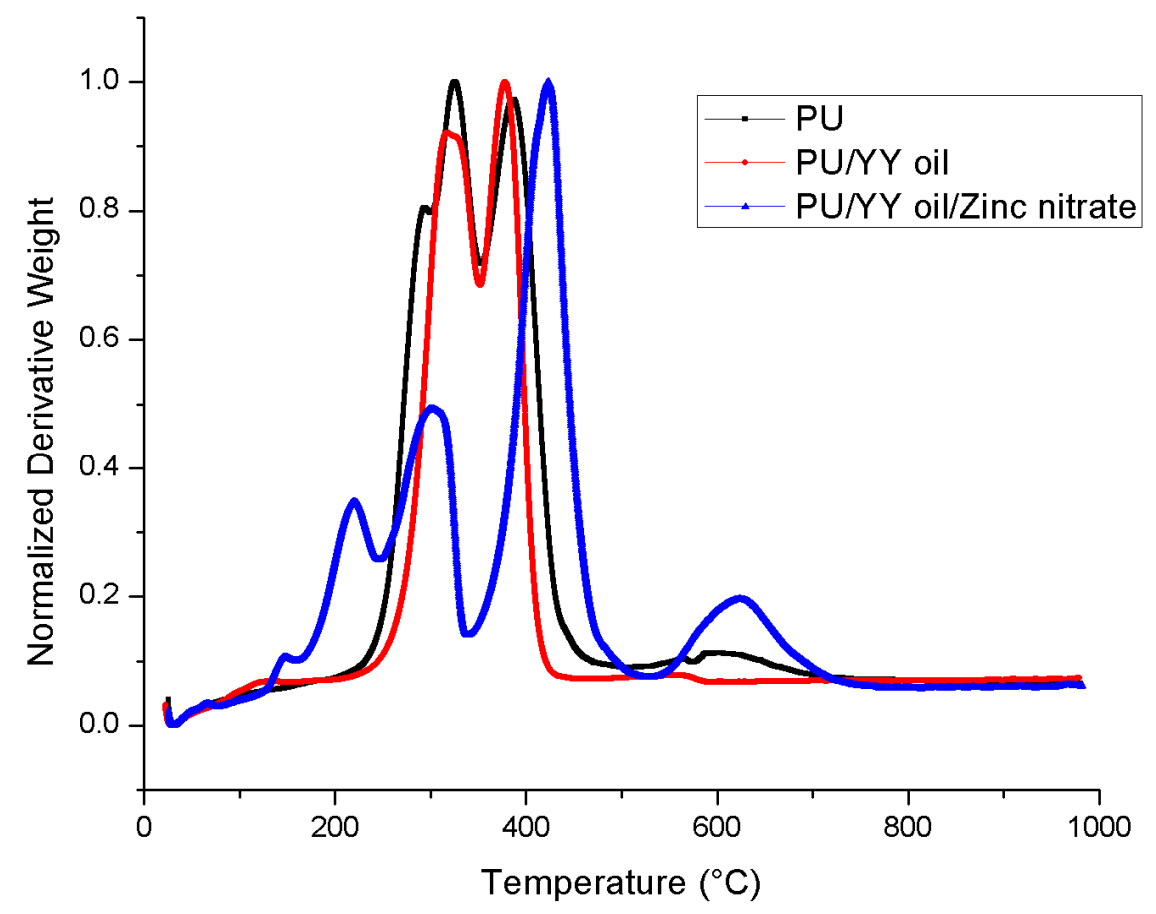

Figure 6. Weight residue of $\mathrm{PU}, \mathrm{PU} / \mathrm{YY}$ and $\mathrm{PU} / \mathrm{YY} / \mathrm{ZnNO}_{3}$. 
Table 1. Weight loss peaks of the electrospun membranes.

\begin{tabular}{cccc}
\hline S.NO & Polyurethane (PU) & PU/Ylang Ylang (YY) & PU/YY/Zinc Nitrate $\left(\mathrm{ZnNO}_{3}\right)$ \\
\hline First weight loss & $210{ }^{\circ} \mathrm{C}$ to $302{ }^{\circ} \mathrm{C}$ & $225{ }^{\circ} \mathrm{C}$ to $351{ }^{\circ} \mathrm{C}$ & $119{ }^{\circ} \mathrm{C}$ to $161{ }^{\circ} \mathrm{C}$ \\
\hline Second weight loss & $302{ }^{\circ} \mathrm{C}$ to $353^{\circ} \mathrm{C}$ & $351{ }^{\circ} \mathrm{C}$ to $470{ }^{\circ} \mathrm{C}$ & $161{ }^{\circ} \mathrm{C}$ to $246{ }^{\circ} \mathrm{C}$ \\
\hline Third weight loss & $353{ }^{\circ} \mathrm{C}$ to $494{ }^{\circ} \mathrm{C}$ & - & $246{ }^{\circ} \mathrm{C}$ to $339{ }^{\circ} \mathrm{C}$ \\
\hline Fourth weight loss & $494{ }^{\circ} \mathrm{C}$ to $760{ }^{\circ} \mathrm{C}$ & - & $339{ }^{\circ} \mathrm{C}$ to $530{ }^{\circ} \mathrm{C}$ \\
\hline Fifth weight loss & - & - & $530{ }^{\circ} \mathrm{C}$ to $780{ }^{\circ} \mathrm{C}$ \\
\hline
\end{tabular}

\subsection{Mechanical Properties}

The mechanical properties of the PU, $\mathrm{PU} / \mathrm{YY}$ and $\mathrm{PU} / \mathrm{YY} / \mathrm{ZnNO}_{3}$ nanocomposites were determined using a tensile test, and their corresponding stress-strain plots are depicted in Figure 7. It was observed that the ultimate tensile strength of $\mathrm{YY}$ and $\mathrm{ZnNO}_{3}$ incorporated nanofibers were higher than pure nanofibers. The tensile strength of the pristine PU was found to be $6.83 \mathrm{MPa}$, whereas PU incorporated with $\mathrm{YY}$ and $\mathrm{YY} / \mathrm{ZnNO}_{3}$ showed a strength of $12.32 \mathrm{MPa}$ and $14.90 \mathrm{MPa}$ respectively. Hence, the addition of $\mathrm{YY}$ and $\mathrm{ZnNO}_{3}$ significantly enhanced the mechanical performance of the pristine PU. Jaganathan et al. developed an electrospun scaffold utilizing polyurethane and copper sulphate. It was found that the incorporation of copper sulphate resulted in the enhancement of the mechanical strength, which correlates with our findings. They reported that this improved mechanical performance resulted from their smaller fiber diameter [35]. Hence, the developed composites showed a smaller fiber diameter than the pristine, which resulted in the improvement of the tensile strength. It has been reported that the mechanical strength in the range between 4 to $10 \mathrm{MPa}$ is suitable for human fetal osteoblast cells response [36]. In the human body, the osteoblast was largely present in the periosteum, which is the thin connective tissue layer that lies outside the surface of bones and in the endosteum [37]. In this research, the reported mechanical strength matches those reported values, indicating its potentiality for periosteum tissue growth.

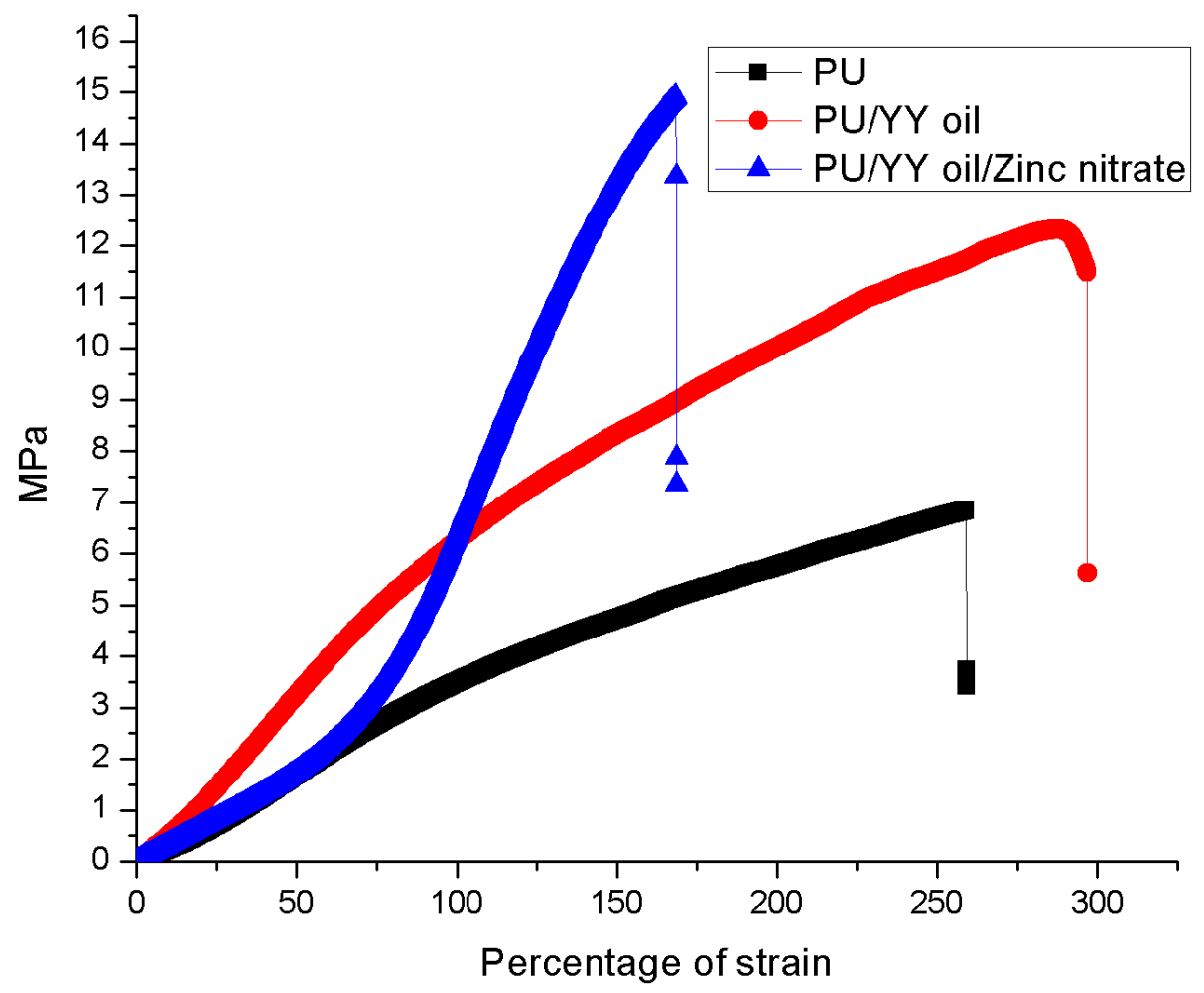

Figure 7. Tensile strength of $\mathrm{PU}, \mathrm{PU} / \mathrm{YY}$ and $\mathrm{PU} / \mathrm{YY} / \mathrm{ZnNO}_{3}$. 


\subsection{AFM Analysis}

Additionally, the surface morphologies of PU, PU/YY, $\mathrm{PU} / \mathrm{YY} / \mathrm{ZnNO}_{3}$ nanocomposite fibers were evaluated by atomic force microscopy. The corresponding AFM images of the as-spun nanofibers are shown in Figure 8. The average surface roughness of the PU was reported to be $776 \mathrm{~nm}$, and the surface roughness of the PU incorporated with $\mathrm{YY}$ and $\mathrm{ZnNO}_{3}$ was found to be $524 \mathrm{~nm}$ and $284 \mathrm{~nm}$, respectively. The $\mathrm{YY}$ and $\mathrm{ZnNO}_{3}$ addition resulted in the reduction of the roughness of the PU, indicating that its surfaces were smooth. Kim et al. investigated the effect of the fiber diameter on the surface roughness of electrospun Poly( $\varepsilon$-caprolactone) scaffolds. It had been found that a scaffold with a smaller fiber diameter showed a smoother morphology and became rougher when the diameter became larger [38]. Hence, our fabricated composites with a smaller fiber diameter might have facilitated the smoother surfaces. Ribeiro developed poly (L-lactide) membranes and investigated the osteoblast cells proliferation. It was found that the surfaces having a low surface roughness displayed an increased adhesion and proliferation of osteoblast cells, compared to the surfaces having a higher surface roughness [39]. Hence, in our study, the lower surface roughness of the developed nanocomposites might be suitable for the enhanced osteoblast cell response.

(a)

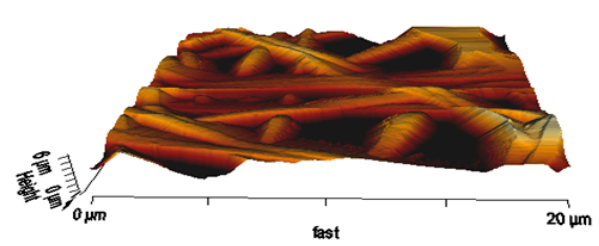

(b)

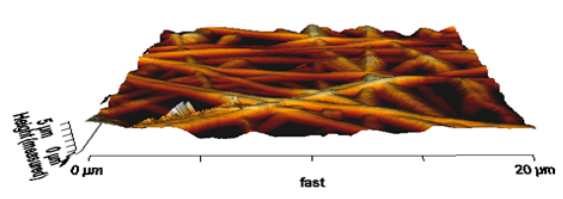

(c)

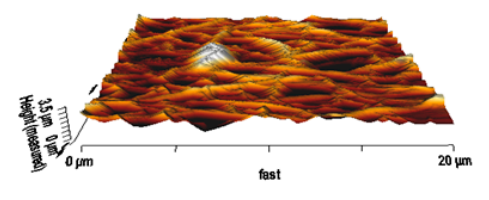

Figure 8. Atomic force microscopy (AFM) images of (a) PU, (b) PU/YY and (c) $P U / Y Y / Z n N O{ }_{3}$.

\subsection{Coagulation Assessments}

The coagulation assay assessments for the electrospun PU, PU/YY and $\mathrm{PU} / \mathrm{YY} / \mathrm{ZnNO}_{3}$ scaffold are presented in Figures 9-11. The APTT time for the electrospun PU/YY and PU/YY/ZnNO 3 scaffold was reported to be $187 \pm 3 \mathrm{~s}$ and $183 \pm 3 \mathrm{~s}$, respectively, whereas for the pristine PU it was $162 \pm 2 \mathrm{~s}$. Similarly, The PT time for the electrospun PU/YY and PU/YY/ZnNO 3 scaffold was reported to be $93 \pm 3 \mathrm{~s}$ and $92 \pm 2 \mathrm{~s}$, respectively, whereas for the pristine PU it was $85 \pm 1 \mathrm{~s}$. The APTT and PT measurements clearly depicted that the developed nanocomposites showed a better compatibility with blood, signified by a prolonging of the blood clotting times when compared to pure polyurethane. This might be due to the presence of $\mathrm{YY}$ and $\mathrm{ZnNO}_{3}$ in the polyurethane matrix. Furthermore, a hemolytic percentage was also performed, in which the pristine PU showed a hemolytic percentage of $2.58 \%$, while for the electrospun $\mathrm{PU} / \mathrm{YY}$ and $\mathrm{PU} / \mathrm{YY} / \mathrm{ZnNO}_{3}$ scaffold the hemolytic percentages were $1.51 \%$ and $1.54 \%$, respectively, indicating non-hemolytic materials, according to ASTMF756-00 (2000) [18]. The blood compatibility measurements depicting a significant delay in blood clotting for the electrospun PU/YY nanocomposites might result from its hydrophobic behaviour. In the blood/surface interaction, the hydrophobic surface will favour the irreversible adhesion of plasma proteins, which results in a delay in the blood clotting time. However, there was variance in the blood clotting times when adding $\mathrm{ZnNO}_{3}$ to the $\mathrm{PU} / \mathrm{YY}$ nanocomposites. This variance was due to the change in the wettability behaviour of the $\mathrm{PU} / \mathrm{YY} / \mathrm{ZnNO}_{3}$ nanocomposites [40]. Jaganathan electrospun polyurethane scaffolds added with corn and neem 
oil. It was observed that the addition of corn and neem oil resulted in enhanced blood clotting times compared to the pristine PU, and the researchers concluded that this might be due to the smaller fiber diameter and hydrophobic nature of the fabricated composites [18]. In this research, the smaller fiber diameter (PU/YY and PU/YY/ZnNO ${ }_{3}$ ) and hydrophobic behaviour (PU/YY) of the electrospun nanocomposites might play a putative role in enhancing the anticoagulant behaviour of the pristine polyurethane.

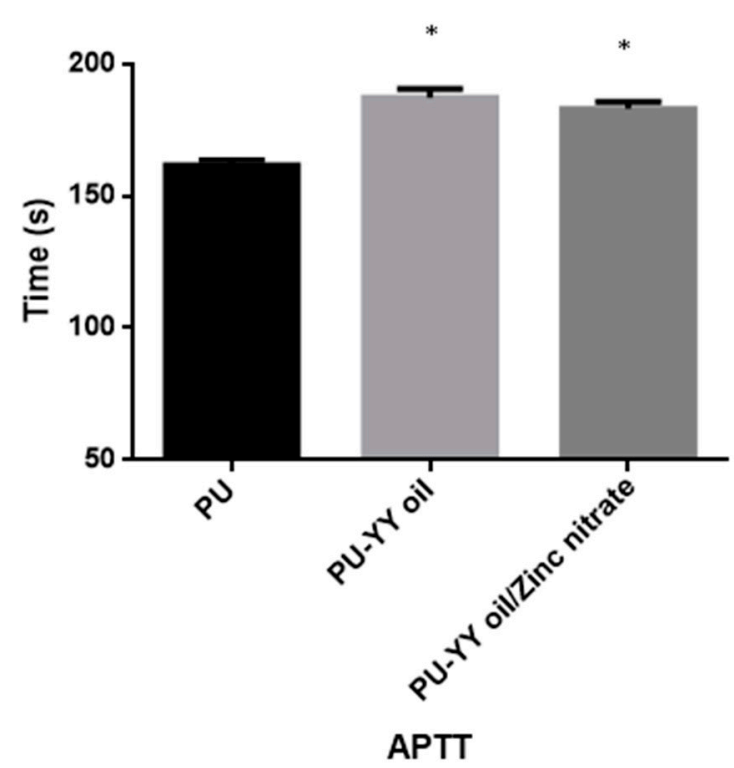

*mean differences were significant compared with pure PU $(\mathrm{p}<0.05)$

Figure 9. Activated Partial Thromboplastin Time (APTT) assay of PU, PU/YY and PU/YY/ZnNO

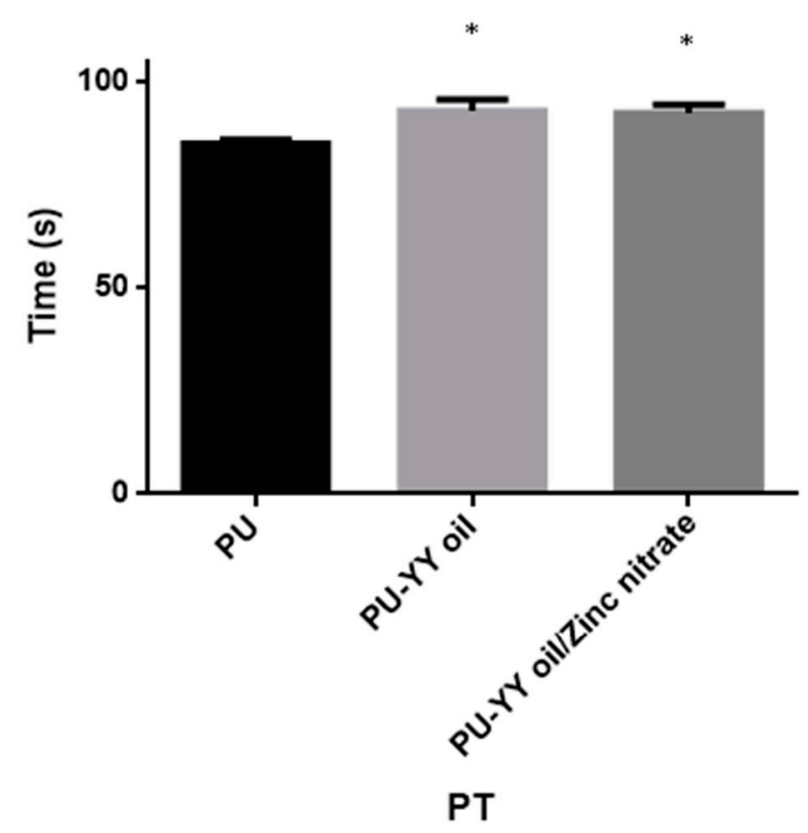

*mean differences were significant compared with pure PU $(\mathrm{p}<0.05)$

Figure 10. Prothrombin Time (PT) assay of PU, PU/YY and PU/YY/ZnNO 


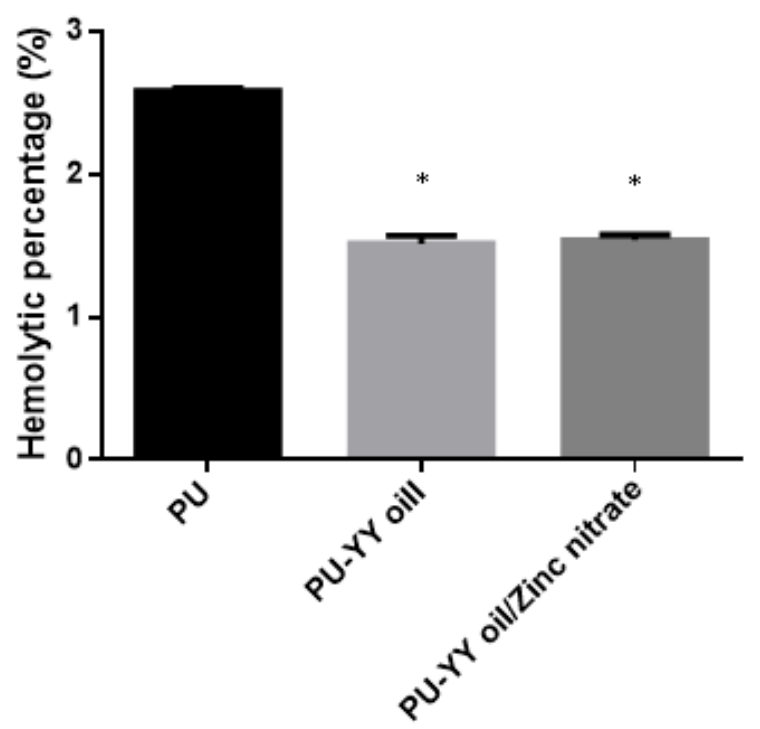

*mean differences were significant compared with pure $\mathrm{PU}(\mathrm{p}<0.05)$

Figure 11. Hemolytic assay of PU, PU/YY and PU/YY/ZnNO 3 .

\subsection{Bone Mineralization Testing}

Figure 12 presents a representation diagram describing the bone mineralization process of the electrospun membranes in SBF after 14 days. It was observed that the presence of YY and zinc nitrate accelerates the calcium deposition in the pristine PU. The weight percentage of calcium deposited in the pristine $\mathrm{PU}$ was found to be $5.323 \%$, and for electrospun PU/YY and $\mathrm{PU} / \mathrm{YY} / \mathrm{ZnNO}_{3}$ it was reported to be $7.919 \%$ and $10.150 \%$, respectively. Hence, the fabricated composites with an improved calcium deposition might serve as potential candidates for bone tissue engineering.

(a)

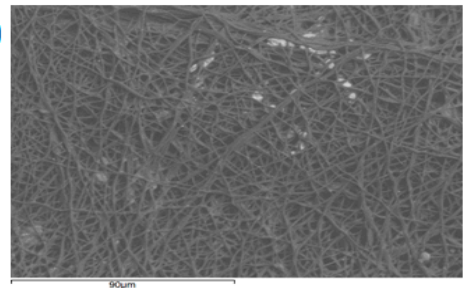

(c)

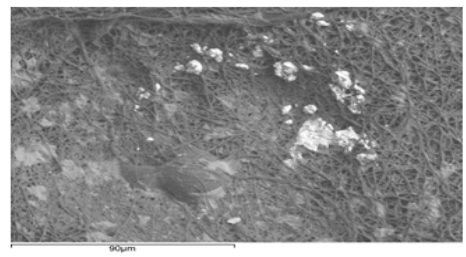

(e)

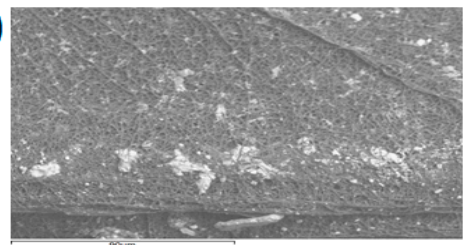

(b)

\begin{tabular}{|c|c|c|c|}
\hline Element & Weight \% & $\begin{array}{c}\text { Weight \% } \\
\text { o }\end{array}$ & Atomic \% \\
\hline Carbon & 75 & 14 & 82 \\
\hline Oxygen & 19 & 5 & 16 \\
\hline Calcium & 5 & 17 & 2 \\
\hline
\end{tabular}

(d)

\begin{tabular}{|c|c|c|c|}
\hline Element & Weight \% & $\begin{array}{c}\text { Weight \% } \\
\sigma\end{array}$ & Atomic \% \\
\hline Carbon & 67 & 9 & 76 \\
\hline Oxygen & 25 & 4 & 21 \\
\hline Calcium & $\mathbf{8}$ & 11 & $\mathbf{3}$ \\
\hline
\end{tabular}

(f)

\begin{tabular}{|c|c|c|c|}
\hline Element & Weight \% & $\begin{array}{c}\text { Weight \% } \\
\sigma\end{array}$ & Atomic \% \\
\hline Carbon & 66 & 11 & 76 \\
\hline Oxygen & 24 & 5 & 20 \\
\hline Calcium & 10 & 15 & 3 \\
\hline
\end{tabular}

Figure 12. Scanning electron microscopy (SEM) and Energy Dispersive X-Ray Spectroscopy (EDX) of calcium deposition of $(\mathbf{a}, \mathbf{b}) \mathrm{PU},(\mathbf{c}, \mathbf{d}) \mathrm{PU} / \mathrm{YY}$ and $(\mathbf{e}, \mathbf{f}) \mathrm{PU} / \mathrm{YY} / \mathrm{ZnNO}_{3}$. 


\subsection{Cytocompatibility Analysis}

The fibroblast cell viabilities of the electrospun PU, PU/YY and PU/YY/ZnNO 3 nanofibrous scaffold using the MTS assay were presented in Figure 13. After a 5 day culture, the PU membrane showed a cell viability in the range of $130 \pm 4 \%$, and for the electrospun PU/YY and PU/YY/ZnNO 3 scaffold it showed a viability of $136 \pm 2 \%$ and $139 \pm 1 \%$, respectively. It was shown that all electrospun membranes showed a better cell viability than the control. Furthermore, the cell viability of the electrospun PU/YY and $\mathrm{PU} / \mathrm{YY} / \mathrm{ZnNO}_{3}$ nanofibers were found to be higher than the pristine PU. As reported earlier, the smaller fiber diameter and hydrophilic behaviour might favour the fibroblast cell adhesion and proliferation. This enhanced cell adhesion of the fibroblast may be due to the reduced fiber diameter (PU/YY and $\mathrm{PU} / \mathrm{YY} / \mathrm{ZnNO}_{3}$ ) and hydrophilic behaviour (PU/YY and $\mathrm{PU} / \mathrm{YY} / \mathrm{ZnNO}_{3}$ ) of the developed composites [41,42]. The periosteum in the human bone is divided into two layers, namely the outer layer which is fibrous and the inner layer which is cambium. The fibrous layer is composed of fibroblasts, while the cambium layer has progenitor cells that grow into osteoblasts [43]. Since our fabricated composites showed a non-toxic behaviour to the fibroblast cells, this indicated the suitability for the growth of periosteum tissue.

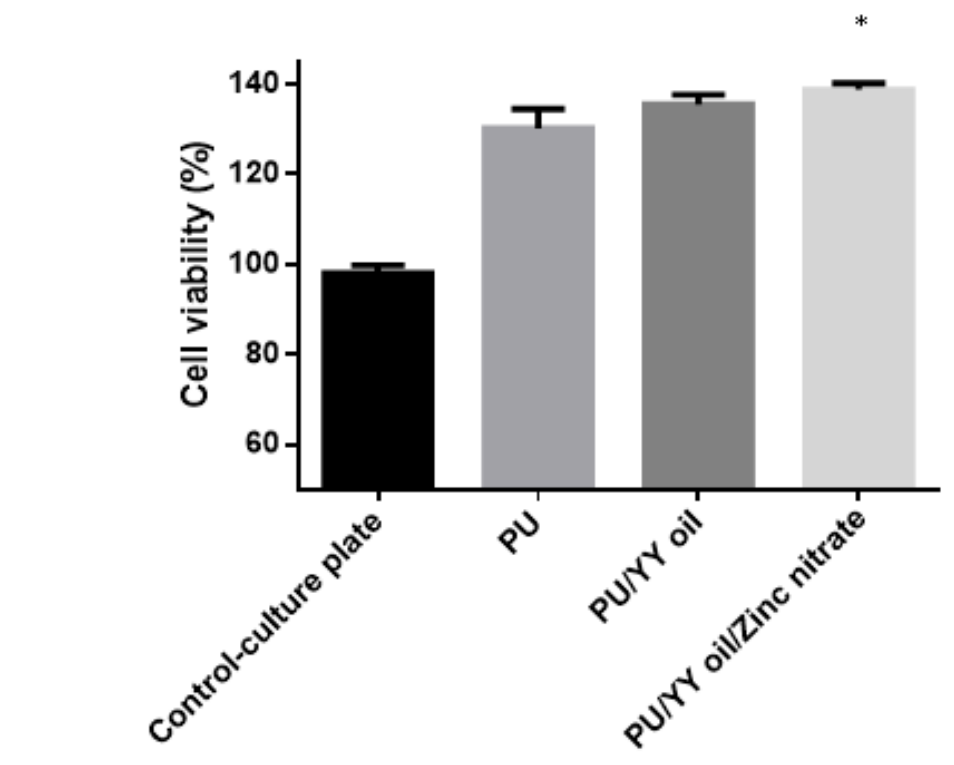

* mean differences were significant compared with pure PU $(\mathrm{p}<0.05)$

Figure 13. Cell viability of $\mathrm{PU}, \mathrm{PU} / \mathrm{YY}$ and $\mathrm{PU} / \mathrm{YY} / \mathrm{ZnNO}_{3}$.

\section{Conclusions}

This research successfully developed a novel scaffold utilizing PU nanofibers added with ylang ylang $(\mathrm{YY})$ and zinc nitrate $\left(\mathrm{ZnNO}_{3}\right)$ using the electrospinning method. The SEM images showed that the diameter of the PU nanofibers was reduced with the addition of $Y Y$ and $\mathrm{ZnNO}_{3}$. FTIR, TGA and XRD analyses confirmed the interactions between PU with $Y Y$ and $\mathrm{ZnNO}_{3}$. The TGA study revealed the improved thermal stability for PU/YY and a slight reduction in the thermal stability for $\mathrm{PU} / \mathrm{YY} / \mathrm{ZnNO}_{3}$. The tensile test indicated that the addition of $Y Y$ and $\mathrm{ZnNO}_{3}$ improved the mechanical properties of the electrospun nanofibers. The electrospun PU/YY and $\mathrm{PU} / \mathrm{YY} / \mathrm{ZnNO}_{3}$ showed a reduced surface roughness when compared with the pristine PU, as depicted in the AFM analysis. The addition of $\mathrm{YY}$ and $\mathrm{ZnNO}_{3}$ improved the anticoagulant and biocompatibility nature of the pristine PU, as depicted in the coagulation and MTS assays. Furthermore, the bone mineralization study depicted the improved calcium deposition in the fabricated composites, when compared with the pristine PU. Hence, the developed composites showed desirable physico-chemical properties, 
biocompatibility and calcium deposition, and might be plausible candidates for bone tissue engineering. However, a thorough in-vivo investigation on the biodegradation and regeneration of the fabricated membranes should be evaluated for further approval.

Author Contributions: Conceptualization, M.P.M., S.K.J. and E.S.; Data curation, M.P.M., S.K.J. and E.S.; Formal analysis, M.P.M., S.K.J. and E.S.; Funding acquisition, S.K.J. and E.S.; Investigation, S.K.J. and E.S.; Methodology, M.P.M., S.K.J.; Project administration, S.K.J. and E.S.; Resources, S.K.J. and E.S.; Software, M.P.M., S.K.J. and E.S.; Supervision, S.K.J. and E.S.; Validation, M.P.M., S.K.J. and E.S.; Visualization, S.K.J. and E.S.; Writing—original draft, M.P.M.; Writing—review \& editing, M.P.M., S.K.J. and E.S.

Funding: This work was supported by High Impact Research Grant (Universiti Teknologi Malaysia) with the Grant No. Q.J130000.2445.04G29.

Conflicts of Interest: The authors declare that they have no conflict of interest.

\section{References}

1. Qi, J.; Zhang, H.; Wang, Y.; Mani, M.P.; Jaganathan, S.K. Development and blood compatibility assessment of electrospun polyvinyl alcohol blended with metallocene polyethylene and plectranthus amboinicus (PVA/mPE/PA) for bone tissue engineering. Int. J. Nanomed. 2018, 13, 2777-2788. [CrossRef] [PubMed]

2. Bone Regeneration. Available online: https://www.sciencedirect.com/topics/medicine-and-dentistry/boneregeneration (accessed on 2 July 2019).

3. Son, S.R.; Linh, N.T.; Yang, H.M.; Lee, B.T. In vitro and in vivo evaluation of electrospun PCL/PMMA fibrous scaffolds for bone regeneration. Sci. Technol. Adv. Mater. 2013, 14, 015009. [CrossRef] [PubMed]

4. Thavornyutikarn, B.; Chantarapanich, N.; Sitthiseripratip, K.; Thouas, G.A.; Chen, Q. Bone tissue engineering scaffolding: Computer-aided scaffolding techniques. Prog. Biomater. 2014, 3, 61-102. [CrossRef] [PubMed]

5. Chan, B.P.; Leong, K.W. Scaffolding in tissue engineering: General approaches and tissue-specific considerations. Eur. Spine J. 2008, 17, 467-479. [CrossRef] [PubMed]

6. Sill, T.J.; Von Recum, H.A. Electrospinning: Applications in drug delivery and tissue engineering. Biomaterials 2008, 29, 1989-2006. [CrossRef] [PubMed]

7. Voytik-Harbin, S.L. Chapter 26 Three-dimensional extracellular matrix substrates for cell culture. Methods Cell Biol. 2001, 63, 561-581. [PubMed]

8. Bhattarai, R.; Bachu, R.; Boddu, S.; Bhaduri, S. Biomedical applications of electrospun nanofibers: Drug and nanoparticle delivery. Pharmaceutics 2019, 11, 5. [CrossRef] [PubMed]

9. Subbiah, T.; Bhat, G.S.; Tock, R.W.; Parameswaran, S.; Ramkumar, S.S. Electrospinning of nanofibers. J. Appl. Polym. Sci. 2005, 96, 557-569. [CrossRef]

10. Huang, Z.-M.; Zhang, Y.-Z.; Kotaki, M.; Ramakrishna, S.; Zhang, Y. A review on polymer nanofibers by electrospinning and their applications in nanocomposites. Compos. Sci. Technol. 2003, 63, 2223-2253. [CrossRef]

11. Wu, S.-C.; Chang, W.-H.; Dong, G.-C.; Chen, K.-Y.; Chen, Y.-S.; Yao, C.-H. Cell adhesion and proliferation enhancement by gelatin nanofiber scaffolds. J. Bioact. Compat. Polym. 2011, 26, 565-577. [CrossRef]

12. Polymer Properties Database. Available online: https://polymerdatabase.com/polymer\%20classes/ Polyurethane\%20type.html (accessed on 29 April 2019).

13. Shen, Z.; Lu, D.; Li, Q.; Zhang, Z.; Zhu, Y. Synthesis and Characterization of Biodegradable Polyurethane for Hypopharyngeal Tissue Engineering. BioMed Res. Int. 2015, 2015, 1-11. [CrossRef] [PubMed]

14. Kumar, N.S.; Santhosh, C.; Sudakaran, S.V.; Deb, A.; Raghavan, V.; Venugopal, V.; Bhatnagar, A.; Bhat, S.; Andrews, N.G. Electrospun polyurethane and soy protein nanofibres for wound dressing applications. IET Nanobiotechnol. 2017, 12, 94-98. [CrossRef]

15. Gencturk, A.; Kahraman, E.; Güngör, S.; Özhan, G.; Özsoy, Y.; Sarac, A.S. Polyurethane/hydroxypropyl cellulose electrospun nanofiber mats as potential transdermal drug delivery system: Characterization studies and in vitro assays. Artif. Cells Nanomed. Biotechnol. 2017, 45, 655-664. [CrossRef] [PubMed]

16. Gabriel, L.P.; Rodrigues, A.A.; Macedo, M.; Jardini, A.L.; Filho, R.M. Electrospun polyurethane membranes for Tissue Engineering applications. Mater. Sci. Eng. C 2017, 72, 113-117. [CrossRef] [PubMed]

17. Jaganathan, S.K.; Mani, M.P.; Nageswaran, G.; Krishnasamy, N.P.; Ayyar, M. Single stage electrospun multicomponent scaffold for bone tissue engineering application. Polym. Test. 2018, 70, 244-254. [CrossRef] 
18. Jaganathan, S.K.; Mani, M.P.; Palaniappan, S.K.; Rathanasamy, R. Fabrication and characterisation of nanofibrous polyurethane scaffold incorporated with corn and neem oil using single stage electrospinning technique for bone tissue engineering applications. J. Polym. Res. 2018, 25, 146. [CrossRef]

19. Chao, C.Y.; Mani, M.P.; Jaganathan, S.K. Engineering electrospun multicomponent polyurethane scaffolding platform comprising grapeseed oil and honey/propolis for bone tissue regeneration. PLOS ONE 2018, 13, e0205699. [CrossRef]

20. De Silva, R.T.; Mantilaka, M.M.M.G.P.G.; Goh, K.L.; Ratnayake, S.P.; Amaratunga, G.A.J.; De Silva, K.M.N. Magnesium Oxide Nanoparticles Reinforced Electrospun Alginate-Based Nanofibrous Scaffolds with Improved Physical Properties. Int. J. Biomater. 2017, 2017, 1-9. [CrossRef]

21. Rodriguez-Tobias, H.; Morales, G.; Ledezma, A.; Romero, J.; Grande, D. Novel antibacterial electrospun mats based on poly(d,1-lactide) nanofibers and zinc oxide nanoparticles. J. Mater. Sci. 2014, 49, 8373-8385. [CrossRef]

22. Tan, L.T.H.; Lee, L.H.; Yin, W.F.; Chan, C.K.; Kadir, H.A.; Chan, K.G.; Goh, B.H. Traditional Uses, Phytochemistry, and Bioactivities of Cananga odorata (Ylang-Ylang). Evidence-Based Complement. Altern. Med. 2015, 2015, 1-30.

23. Forero, J.C.; Roa, E.; Reyes, J.G.; Acevedo, C.; Osses, N. Development of Useful Biomaterial for Bone Tissue Engineering by Incorporating Nano-Copper-Zinc Alloy (nCuZn) in Chitosan/Gelatin/Nano-Hydroxyapatite (Ch/G/nHAp) Scaffold. Materials 2017, 10, 1177. [CrossRef] [PubMed]

24. Linh, N.T.; Lee, B.T. Electrospinning of polyvinyl alcohol/gelatin nanofiber composites and cross-linking for bone tissue engineering application. J. Biomater. Appl. 2012, 27, 255-266. [CrossRef] [PubMed]

25. Prabhakaran, M.P.; Venugopal, J.; Ramakrishna, S. Electrospun nanostructured scaffolds for bone tissue engineering. Acta Biomater. 2009, 5, 2884-2893. [CrossRef] [PubMed]

26. Lawrence, B.J.; Madihally, S.V. Cell colonization in degradable 3D porous matrices. Cell Adhes. Migr. 2008, 2, 9-16. [CrossRef] [PubMed]

27. Noriega, S.E.; Hasanova, G.I.; Schneider, M.J.; Larsen, G.F.; Subramanian, A. Effect of fiber diameter on the spreading, proliferation and differentiation of chondrocytes on electrospun chitosan matrices. Cells Tissues Organs 2012, 195, 207-221. [CrossRef] [PubMed]

28. Guo, Z.; Ma, M.; Huang, X.; Li, H.; Zhou, C. Effect of Fiber Diameter on Proliferation and Differentiation of MC3T3-E1 Pre-Osteoblasts. J. Biomater. Tissue Eng. 2017, 7, 162-169. [CrossRef]

29. Mani, M.P.; Jaganathan, S.K. Physicochemical and blood compatibility characteristics of garlic incorporated polyurethane nanofibrous scaffold for wound dressing applications. J. Text. Inst. 2019, 6, 1-9. [CrossRef]

30. Unnithan, A.R.; Pichiah, P.T.; Gnanasekaran, G.; Seenivasan, K.; Barakat, N.A.; Cha, Y.-S.; Jung, C.-H.; Shanmugam, A.; Kim, H.Y. Emu oil-based electrospun nanofibrous scaffolds for wound skin tissue engineering. Colloids Surfaces A Physicochem. Eng. Asp. 2012, 415, 454-460. [CrossRef]

31. Wei, J.; Igarashi, T.; Okumori, N.; Igarashi, T.; Maetani, T.; Liu, B.; Yoshinari, M. Influence of surface wettability on competitive protein adsorption and initial attachment of osteoblasts. Biomed. Mater. 2009, 4, 45002. [CrossRef]

32. Liang, C.; Luo, Y.; Yang, G.; Xia, D.; Liu, L.; Zhang, X.; Wang, H. Graphene Oxide Hybridized nHAC/PLGA Scaffolds Facilitate the Proliferation of MC3T3-E1 Cells. Nanoscale Res. Lett. 2018, 13, 15. [CrossRef]

33. Zhang, Y.; Zhu, F.; Zhang, J.; Xia, L. Converting Layered Zinc Acetate Nanobelts to One-dimensional Structured ZnO Nanoparticle Aggregates and their Photocatalytic Activity. Nanoscale Res. Lett. 2008, 3, 201-204. [CrossRef]

34. Jaganathan, S.K.; Mani, M.P. Single-stage synthesis of electrospun polyurethane scaffold impregnated with zinc nitrate nanofibers for wound healing applications. J. Appl. Polym. Sci. 2019, 136, 46942. [CrossRef]

35. Jaganathan, S.K.; Mani, M.P. Electrospun polyurethane nanofibrous composite impregnated with metallic copper for wound-healing application. 3 Biotech 2018, 8, 327. [CrossRef] [PubMed]

36. Salifu, A.A.; Lekakou, C.; Labeed, F.H. Electrospun oriented gelatin-hydroxyapatite fiber scaffolds for bone tissue engineering. J. Biomed. Mater. Res. Part. A 2017, 105, 1911-1926. [CrossRef] [PubMed]

37. Anatomy and Physiology. Available online: https://opentextbc.ca/anatomyandphysiology/chapter/6-3-bonestructure/ (accessed on 2 July 2019).

38. Kim, H.H.; Kim, M.J.; Ryu, S.J.; Ki, C.S.; Park, Y.H. Effect of fiber diameter on surface morphology, mechanical property, and cell behavior of electrospun poly ( $\varepsilon$-caprolactone) mat. Fiber Polym. 2016, 17, 1033-1042. [CrossRef] 
39. Ribeiro, C.; Sencadas, V.; Areias, A.C.; Gama, F.M.; Lanceros-Méndez, S. Surface roughness dependent osteoblast and fibroblast response on poly (l-lactide) films and electrospun membranes. J. Biomed. Mater. Res. Part. A 2015, 103, 2260-2268. [CrossRef]

40. Szycher, M. High Performance Biomaterials: A Complete Guide to Medical and Pharmceutical Applications; Routledge: London, UK, 2017.

41. Tian, F.; Hosseinkhani, H.; Hosseinkhani, M.; Khademhosseini, A.; Yokoyama, Y.; Estrada, G.G.; Kobayashi, H. Quantitative analysis of cell adhesion on aligned micro-and nanofibers. J. Biomed. Mater. Res. Part. A 2008, 84, 291-299. [CrossRef]

42. Nandakumar, V.; Suresh, G.; Chittaranjan, S.; Doble, M. Synthesis and Characterization of Hydrophilic High Glycolic Acid-Poly(d,1-Lactic-co-Glycolic Acid)/Polycaprolactam/Polyvinyl Alcohol Blends and Their Biomedical Application as a Ureteral Material. Ind. Eng. Chem. Res. 2012, 52, 751-760. [CrossRef]

43. Periosteum. Available online: https://en.wikipedia.org/wiki/Periosteum (accessed on 2 July 2019).

(C) 2019 by the authors. Licensee MDPI, Basel, Switzerland. This article is an open access article distributed under the terms and conditions of the Creative Commons Attribution (CC BY) license (http://creativecommons.org/licenses/by/4.0/). 